\title{
Antibacterial Activity of Soaps used in Different Households: Case Study of Susa Village, Musanze, Rwanda
}

\section{Callixte Yadufashije $^{1 *}$, Grace Uwanyagasani ${ }^{1}$, Francois Niyonzima $^{1}$, Jean Claude Dusabumuremyi ${ }^{2}$, Madjidi Sibomana ${ }^{1}$, Emmanuel Munyeshyaka ${ }^{1}$, Joseph Mucumbitsi ${ }^{1}$, Thierry HABYARIMANA ${ }^{1}$}

${ }^{1}$ Department of Biomedical Laboratory Sciences, Faculty of Applied Fundamental Sciences, INES Ruhengeri-Institute of Applied Sciences, Musanze, Rwanda, ${ }^{2}$ Department of Biotechnologies, Faculty of Applied Fundamental Sciences, INES Rubengeri-Institute of Applied Sciences, Musanze, Rwanda.

\begin{abstract}
Background: Soap is a solution used to lessen the number of living microorganisms on the surface of the skin, clothes, toilet and materials. It is a cleaning agent made by the chemical action of alkali on fats or fatty acids to yield the sodium or potassium salts of these acids. Objective : This study was carried out to assess antibacterial activity of common soaps used in Rwanda. Materials and methods: This was a cross-sectional study conducted in Susa Village, Musanze District, Rwanda. Skin, clothe, toilets and household used materials were taken as sample sites. Swabs were collected and taken in INES Ruhengeri microbiology laboratory to isolate and identify bacteria, and perform antimicrobial activity of soaps. Results: The most isolated bacteria were Citrobacter spp . (40\%), P. aeruginosa and Enterobacter spp .(13.5\%), S. aureus and E. coli (10.8\%), Proteus spp . and Klebsiella spp . were isolated at 5.4\%. Toilet gel and hand washing soap had the highest antibacterial compared to other soaps. Toilet gel antibacterial activity observed as indicated: E. coli $(18 \mathrm{~mm})$, Enterobacter spp.$(15 \mathrm{~mm})$ and S. aureus at $14 \mathrm{~mm}$, while for hand washing soap were seen as follows E.coli $(24 \mathrm{~mm})$, followed by proteus $(15 \mathrm{~mm})$, Klebsiella $(13 \mathrm{~mm})$ and S .aureus $(14 \mathrm{~mm})$ however Enterobacter and Citrobacter were resistant to hand washing soap. Duru soap showed the property to inhibit growth of S.aureus. but its antibacterial property was not effective to other bacteria. Clear and Tembo were not effective prevent the growth of bacteria. Conclusion: Hand washing soap, toilet gel could be used as antimicrobial agents. Clear, Tembo can be used to remove duties and oil on skin, clothes and materials.duru soap can be used as beauty soap.
\end{abstract}

Keywords: Soap, Antimicrobial, Bacteria, Microorganisms, Skin

Editor | Muhammad Nauman Zahid, Quality Operations Laboratory, University of Veterinary and Animal Sciences, Lahore, Pakistan.

Received | March 20, 2020 Accepted | July 20, 2020; Published | August 10, 2020

*Correspondence | Callixte Yadufashije, Department of Biomedical Laboratory Sciences, Faculty of Applied Fundamental Sciences, INES Ruhengeri-Institute of Applied Sciences, Musanze, Rwanda; Email: cyadufashije@gmail.com

Citation | Yadufashije C, Uwanyagasani G, Niyonzima F, Dusabumuremyi JC, Sibomana M, Munyeshyaka E, Mucumbitsi J, Habyarimana T (2020). Antibacterial activity of soaps used in different households: case study of Susa village, Musanze, Rwanda S. Asian J. Life Sci. 8(2): 42-48.

DOI | http://dx.doi.org/10.17582/journal.sajls/2020/8.2.42.48

ISSN | 2311-0589

Copyright $(92020$ Yadufashije et al. This is an open access article distributed under the Creative Commons Attribution License, which permits unrestricted use, distribution, and reproduction in any medium, provided the original work is properly cited.

\section{INTRODUCTION}

$\mathrm{A}$ ntimicrobial designed soaps are known as a solution to reduce the number of microbes on the surface of the skin and other different materials used in household (Teniola et al., 2019). They are usually rubbed on the skin during hand washing or bathing. the most common accessible of the antimicrobial products is soap (Akuoko, 2019), the main function of antimicrobial soaps is to fight against pathogenic microbes that commonly live (colonize) the surface of the skin. These include bacteria in the genera of staphylococcus and streptococcus (Adebayo et al., 2018). Normally, these bacteria are innocuous, do not cause harm to the host but if they gain access to niches inside the body due to a cut or other injury, they can cause serious and even life-threatening diseases. For example, folliculitis caused by staphylococcus aureus. By hand washing with an antimicrobial soap for an adequate length of time at least one minute to lessen the number of living $S$. aureus on the skin prior to heart valve surgery (Saba et al., 2009). 
The use of antibacterial soap began in the mid-nine-teenth century. From this time, Ignaz Semmelweiss (1818-1865) noted the markedly higher death rate among hospitalized patients who received care from medical students, versus patients cared for by midwives. hand washing with soap and water have been considered to be a measure of personal hygiene. The principle ingredient that has been most commonly used in antimicrobial soaps is known as triclosan. The compound contains a phenol ring structure to which it attaches on chlorine groups. The phenol ring is very difficult to be broken apart, and this make it stable not to be degraded by bacteria and fungi (Abbas et al, 2009).

Both Gram Positive and Gram negative bacteria are deposited from the environment on the surface of skin and causes skin infection. Examples of these bacteria include Staphylococcus aureus, Bacillus subtilis and Pseudomonas aeruginosa. Spread of infection by such bacteria can be prevented by use of antiseptic soaps, as it contains antimicrobial chemicals, but over use of soaps might be a leading cause of antimicrobial resistance and even rendering a person more sensitive to allergy. According to Osborne and Grube (1982) antibacterial soap can remove about 65-85\% of bacterial flora from human skin. As skin is the first line of defense, so most of the bacteria like Pseudomonas aureginosa and Staphylococcus aureus reside on skin and is the major cause of skin infections (Varsha, 2016).

Some people consider that the antibacterial portion of soaps as effective against microorganisms and can prevent most of infectious diseases (Allison et al., 2007), but studies found that too much use of antibacterial soaps can be a major cause of spreading diseases instead of preventing them. Much use of medicated soaps might result in a resistant strain, and then the person is more prone to opportunistic skin infections (Abbas et al., 2016). However, hand hygiene is always important as hands carry food handlers. Food handler includes those who deals with delivers and serve food (Horton et al., 2002).

According to Osborne and Grobe, (1982) antimicrobial soap can remove approximately $60-85$ percent of bacteria flora from human skin. It means the remaining percentage can contribute to develop infections of the skin but also to maintain healthy skin. Other study conducted by Varsha (2016) also showed that S. aureus and P. aeruginosa remain reside on the skin and they are major cause of the skin infection. In the study done by (Saba et al., 2009) stated that too much use of soaps and overuse of soaps might contribute to bacterial resistance. It also has the opposite effect by spreading diseases or infections instead of preventing them. Therefore, this study is going to assess the antimicrobial activity of different soaps used at home and testing their ability to kill or the bacteria present on the skin (Saba et al., 2009).

\section{MATERIALS AND METHODS}

\section{Study Area}

This study was conducted at Susa village located in Muhoza sector, Musanze district, Northern Province of Rwanda.

\section{Study Design}

This was a cross sectional study carried out to analyze antimicrobial activity of soap used in different household, the target population are people living in SUSA Village, Muhoza Sector, Musanze District, and North Province. The swab samples were collected from the skin of human and material used in household and analyzed in clinical microbiology laboratory of INES-Ruhengeri-Institute of Applied Sciences.

\section{Target Population}

The target population of the study was the members of different family based on household located in Susa village.

\section{Sample Collection}

The medicated and toilet soap samples used for the study were purchased from standard cosmetics and pharmacy stores in Musanze. The batch numbers, expiry dates and the presence or absences of the manufacturers seal were noted. Sterile swab sticks were moistened with sterile peptone water, and was used to collect skin swabs samples from the neck, armpit, chest, face and hand of people live in Susa village. The skin areas sampled were first swabbed with methylated spirit to remove the transient micro flora

\section{Isolation of Microorganisms}

Samples collected with swab sticks was then used to inoculate prepared blood and Macconckey Agar (Biotech, England) plates. The cultured plates were incubated at $37^{\circ} \mathrm{C}$ for 48 hours. Biochemical characterization and identification of the test pathogens was carried out using standard identification manual.

\section{LABORATORY AnaLYSIS}

\section{Preparation of Soap Samples}

A sterile blade was used to scrap one gram $(1 \mathrm{~g})$ each of the soaps and which quantity was dissolved in $3 \mathrm{mls}$ of sterile distilled water to a give a stock solution of $10^{-1}$. These stock solutions were then stored in a refrigerator in well-sealed containers for future use.

\section{Preparation of Disks with Soap Samples}

Disks of diameter $6 \mathrm{~mm}$ were bored using disc borer. The discs were then wrapped in foil paper and sterilized in a hot air oven at $100^{\circ} \mathrm{C}$ for 1 hour and were later soaked in the different soap solutions for a period of one hour to ensure full saturation of the soap preparations. The discs were then aseptically removed from soap solution and allowed 
to dry in an oven at $25^{\circ} \mathrm{C}$. They were then packed into sterile bottles, corked and stored in the refrigerator for future use in susceptibility test.

\section{Culture Media preparation}

Blood agar, macconckey agar and Mueller Hinton agar (M1084-500G) were prepared by dissolving some grams of given amount of dehydrated culture media to 1 liter of distilled water. Heated with repeated stirring and boiled for 1 minute to dissolve completely. Then the prepared solution was autoclaved at $121{ }^{\circ} \mathrm{C}$ for 15 minutes, then cools down and distributed in the Petri dish and waited for culture medium to be solidified.

\section{INOCULATION AND INCUBATION}

Pour plate method was used for inoculation of bacteria samples into prepared Petri dishes of blood media, macconckey media. The plates were aerobically incubated at $35-37^{\circ} \mathrm{C}$ for $18-24 \mathrm{hrs}$. Then examine the grown colonies.

\section{GRAM STAINING}

The isolated colonies from blood agar were Gram stained. A single colony was taken on slide, then normal saline added, and a smear made in a circular shape. The crystal violet solution was first applied and allowed to remain 1 min.tap water was added to rinse the smear. Iodine solution was added applied for 1 min.tap water was added again to rinse the smear. The decolorizer was applied for 1 to $5 \mathrm{~s}$. then tap water added to rinse the smear. The safranin solution as a counter stain applied for 30 s.tap water was used again for the same purpose and the slides allowed drained and dried in an upright position. Microscopic test was done with $100 x$ oil immersion to identify gram negative bacteria and gram positive baria.gram positives stain purple while gram negative stain red.

\section{BiOCHEMICAL TEST}

Depending on the bacteria pathogen isolated and the morphology characteristics, the ideal biochemical tests were performed

\section{Citrate TEST}

The preparation of simmon citrate agar (TM MEDIA, India) was carried out using of $24.28 \mathrm{~g}$ in 11.this was followed by heating to dissolve the medium and sterilization of the mixture in autoclave (Huatai-YX280) at $121^{\circ} \mathrm{c}$ for $15 \mathrm{~min}$. test tubes were sterilized for inoculation. This was poured into those labelled test tubes in inverted position then solidification followed a loop for inoculation was sterilized using a flame. Referring to the labels, a sterilize red loop was used to select and isolate the colony into the petri dish to be cultured in each test tube.in $18-24 \mathrm{hrs}$, all the test tubes were incubated at 37 .

\section{Motility, Indole TeSTS AND $\mathrm{H}_{2} \mathrm{~S}$ PRODUCTION}

$30 \mathrm{~g}$ of sulfide indole and motility medium (BBL,India) was introduced in 11.heating to dissolve the medium followed and the mixture was sterilized in autoclave (Huatai YX280) at $121^{\circ} \mathrm{c}$ for $15 \mathrm{~min}$.test tubes were sterilized for inoculation .then kovac's reagents were introduced on SIM's test tubes as indole reagent after incubation.

\section{LACTOSE FERMENTATION}

Using 57.52g of kligler iron agar (TM MEDIA, India) in 11 of distilled water,te prepared mixture was heated to dissolve the medium and sterilized in autoclave (Hutai YX280D) at $121^{\circ} \mathrm{c}$ for 15 min.after cooling at $45^{\circ} \mathrm{c}$, the medium was poured into labelled test tubes in inverted position then solidification followed .a loop for inoculation was sterilized using a flame. Referring to the labels, a sterilize red loop was used to select and isolate the colony into the petri dish to be cultured in each test tube.in 18-24hrs, all the test tubes were incubated at 37 for 18-24hrs.

\section{UREASE TEST}

The urease test is performed by inoculating the test organism in a medium containing urea and phenol red indicator. The test is performed by picking the test organism and then streaking the slope first and finally stabbing the bottom and incubated overnight at $35-37^{\circ} \mathrm{C}$. A urease producing organism breaks down the urea to produce ammonia and carbon dioxide. Ammonia causes the medium to be alkaline, this is seen in the change of color of the indicator to pink.

\section{OXIDASE TEST}

The oxidase test was performed to aid in the identification of Pseudomonas. Filter paper was soaked with few drops of oxidase reagent. Test organism was smeared on the filter paper. Oxidase producing organism oxidises the phenylenediamine in the reagent showing a deep purple color.

\section{TRIPLE SUGAR IRON TEST}

An inoculating straight loop was sterilized in the blue flame of the Bunsen burner and then allowed to cool. A colony of the suspected organism form Macconckey agar was picked, stabbed into the medium up to the butt of the TSI tube and then it was streaked back and forth along the surface of the slant. Again the neck of the TSI was flamed, capped and placed in the incubator for 18-24 hours at a temperature of $37^{\circ} \mathrm{C}$.

\section{Catalase TEST}

2 drops of $3 \%$ hydrogen peroxide were put onto a clean glass slide using a dropper, a pure colony of the organism was picked from blood agar using a wire loop. Placing the colony on the hydrogen peroxide on the glass slide; emulsification was done. Observation for bubble formation was 
done within 30 seconds.

Coagulase test

Dilute plasma from human blood was used with peptone water. A loopful of the test organism was put into the diluted plasma which made a complete suspension. Incubation of the suspension was done at a temperature of $37{ }^{\circ} \mathrm{C}$ then examination for clot formation was made.

\section{Antimicrobial Susceptibility Testing}

Disk Agar Diffusion Method: The disk agar diffusion method was used. Mueller- Hinton agar plates was prepared for the isolates. Plates dried with their lids ajar (slightly raised) at a temperature of $60^{\circ} \mathrm{C}$ in the oven for 15 minutes. The test organisms from growth on macconckey (KIA biochemical) agar plates incubated at $37^{\circ} \mathrm{C}$ were suspended in saline solution $(0.85 \% \mathrm{Nacl})$ and adjusted to match a turbidity of $0.5 \mathrm{McF}$ arland Standard. The standardized suspension was used to inoculate the surfaces of Mueller Hinton agar plates using sterile cotton swab. The plates were left for about 30 minutes; the disks were aseptically transferred directly into the sensitivity plates with the aid of a sterile forceps. Within 30 minutes of application, plates were inverted, incubated at $35^{\circ} \mathrm{C}$ for $24 \mathrm{hrs}$ and then were examined for of zone of inhibition around the disk minutes.

From the tubes which showed no growth into a fresh medium lacking the varying concentration of soap samples. The lowest soap concentration from which the microorganisms did not grow when transferred to a fresh medium is the MBC.

\section{ETHical Considerations}

The study obtained approval from the Executive secretary of Ruhengeri cell. This study also applied and was granted ethical clearance form INES-Ruhengeri research committee. Informed people consent form was sought and obtained through writing from participants. All people's data gathered in this study were handled confidentially by the researcher. Furthermore, laboratory coding was used to identify sample from whom the data was obtained.

\section{Statistical Analysis}

Data entry and analysis was done by using statistical package for social sciences version 22 (SPSS v, 22). the quantitative data was analyzed using descriptive statistics summarized and displayed on figures and graph.

\section{RESULTS}

Table 1: Sampling Site of Bacteria

\begin{tabular}{|ll|r|r|r|r|}
\hline & & & & \multicolumn{1}{c|}{$\begin{array}{c}\text { Cumulative } \\
\text { Percent }\end{array}$} \\
\hline Valid Clothes & 6 & 16.2 & 16.2 & 16.2 \\
& Skin & 24 & 64.9 & 64.9 & 81.1 \\
& Toilette & 4 & 10.8 & 10.8 & 91.9 \\
Materials & 3 & 8.1 & 8.1 & 100.0 \\
Total & 37 & 100.0 & 100.0 & \\
\hline
\end{tabular}

Table 1 this table show the percentage of the sample collected for the study. skin samples were collected at $64.9 \%$, followed by clothes samples collected at $16.2 \%$, toilette sample was collected at $10.8 \%$ and materials was collected at $8.1 \%$.

\section{IDENTIFIED BACTERIA FROM DIFFERENT SAMPLE}

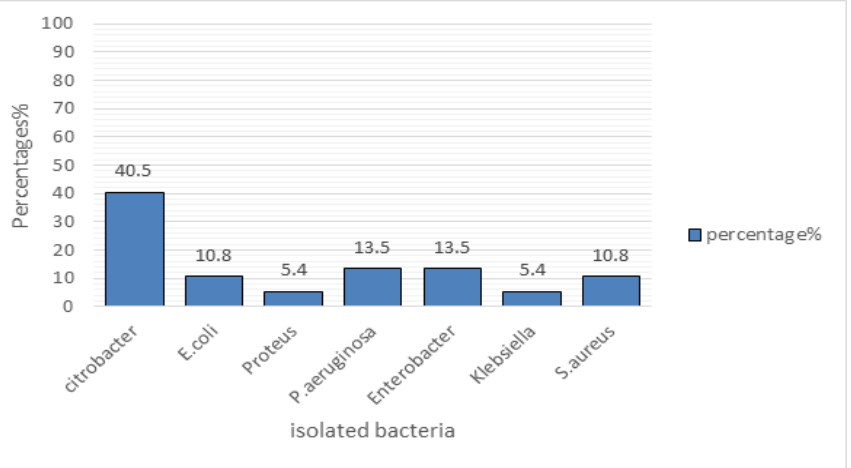

Figure 1: Identified bacteria

The Figure 1 shows the percentage of the isolated bacteria, Citrobacter (40.5\%) was the most isolated bacterium followed by P.aeruginosa at $13.5 \%$ and Enterobacter atthe same of $13.5 \%$, E.coli and S. aureus was isolated at $10.8 \%$, Proteus and Klebsiella was isolated at $5.4 \%$.

\section{Isolated Bacteria And Sample Source Area}

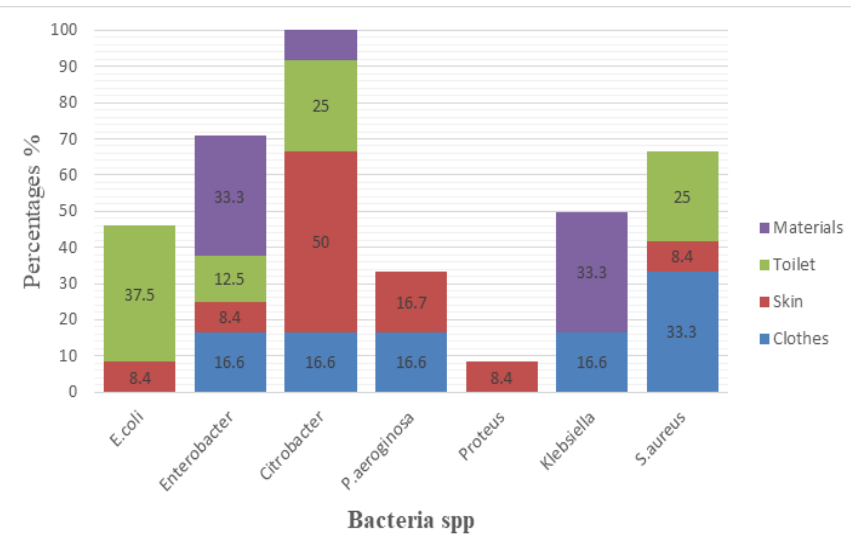

Figure 2: Isolated bacteria and sample source 
The Figure 2 shows the different isolated bacteria and their source of sample, E.coli was isolated from toilet at $37.5 \%$, and were isolated on skin at $8.4 \%$. Enterobacter was isolated from material at $33.3 \%$, on toilet were isolated at 12.5 , while on skin were at $8.4 \%$, on Clothes were at $16.6 \%$. Citrobacter was isolated from materials at $33.3 \%$, and were isolated from toilet at $25 \%$, on skin were isolated at $50 \%$ while on clothes was isolated at $16.6 \%$. Paeruginosa was isolated from skin at $16.7 \%$ while on clothes were isolated at 16.6. Proteus was isolated on skin at $8.4 \%$. Klebsiella was isolated on material at $33.3 \%$,on clothes were isolated at $16.6 \%$. S.aureus was isolated from toilet at $25 \%$, on skin were isolated at $8.4 \%$ while on Clothes were isolated at $33.3 \%$.

\section{Antimicrobial Susceptibility of Toilet Gel} Against Bacteria Strain Isolated from Toilet Figure 3 shows the antimicrobial susceptibility of toilet gel against bacteria strain isolated from toilet. The results exhibited a strong effectivity on E. coli at $18 \mathrm{~mm}$ followed by Enterobacter spp. at $15 \mathrm{~mm}$ and $S$. aureus at $14 \mathrm{~mm}$. The component of soap used has ability to inhibit the growth of Citrobacter spp which is less effectively.

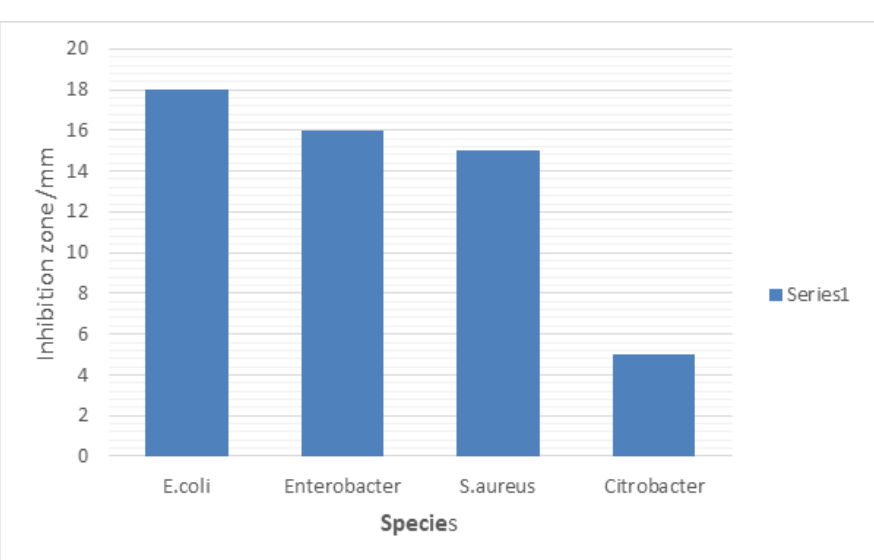

Figure 3: Antimicrobial activity of toilet gel against bacteria strain isolated from toilet

\section{Antimicrobial Activity of Soaps on Human Materials}

The Figure 4 shows the antimicrobial activity of different soap used in household such as Duru, clear.tembo and hand washing soap against bacteria species isolated from skin, clothes and materials used at home. Hand washing soap was more effective to E.coli at maximum zone of inhibition $(24 \mathrm{~mm})$, followed by proteus $15 \mathrm{~mm}$, Klebsiella at $13 \mathrm{~mm}$ and S.aureus at $14 \mathrm{~mm}$ but Enterobacter and Citrobacter is resistant to hand washing soap. Duru has effective to S.aureus at $10 \mathrm{~mm}$ while Klebsiella, Enterobacter, Citrobacter, proteus, E.coli, P. aeruginosa are resistant. Clear soap is less effective to Klebsiella but Enterobacter spp., Citrobacter spp., S. aureus, E.coli, Proteus and P. aeruginosa are re- sistant to it. The following bacteria Klebsiella, Enterobacter spp., Citrobacter spp., S.aureus, E.coli, Proteus, P. aeruginosa are resistant to Tembo soap.

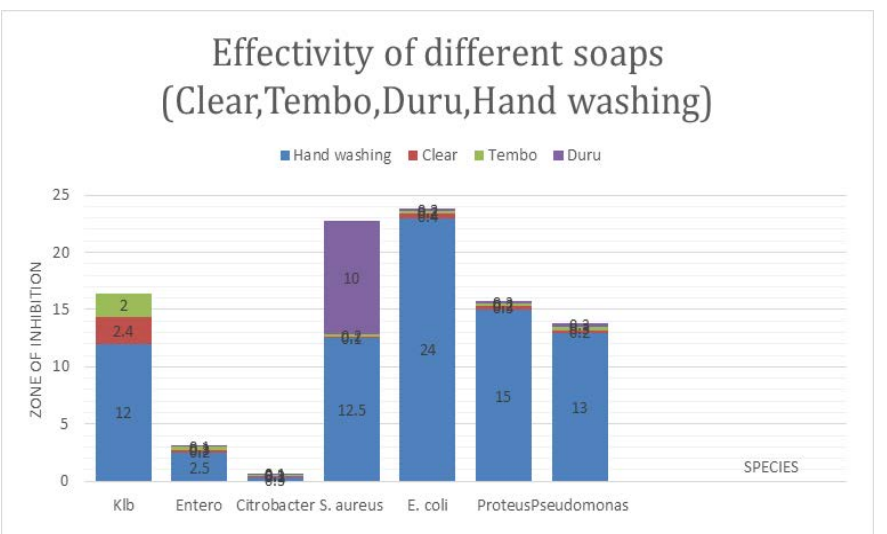

Figure 4: Antimicrobial activity of soaps on human materials

\section{DISCUSSION}

Bacteria were isolated from different samples collected from toilets, clothes, human skin and home materials. Citrobacter spp. was the most isolated bacteria at $40.5 \%$, Paeruginosa and Enterobacter were the second isolated bacteria both stood at $13.5 \%$, S.aureus and E.coli both counting 10.8\%, Klebsiella and Proteus were isolated at $5.4 \%$ Fi gure 1. Gram negative bacteria were the most isolated from skin, materials and clothes compared to Gram positive bacteria, this could be due to the nature of the skin, material, or required nutrient and living conditions.. Gram-positive cocci $S$. aureus was mostly isolated bacteria from clothes, Figure 2. Staphylococcus aureus is a facultative anaerobe bacterium, it is a major cause of skin and soft tissue infections (SSTI) such as impetigo (Gould, 2009). Comparative studies on the effect of locally made black soap and conventional medicated soaps on isolated human skin micro flora investigated The effect of locally made black soap and conventional medicated soaps Dettol, Duru osun, Zee and Tura on isolated human skin micro flora using disk diffusion method. The organisms isolated as skin microbiota were Staphylococcus aureus (30\%), Staphylococcus epidermidis (26\%), Corynebacterium spp (22\%), Bacillus spp (16\%) and Escherichia coli (6\%) (Ikpoh et al, 2012). This study has similarities with the current study, despite differences on considered samples. Some bacteria are the same due to skin swab similarities while others are different due two other samples taken fromother sources by the current study.

The current fundings are in agreement with the study of Chiller et al. (2011) done in California about skin micro flora and bacterial infection of the skin where Staphylococcus, Micrococcus, and Corynebacterium spp were pathogenic 
bacteria isolated from the skin. However, the current study was not looking skin infections, but it considered skin swab to identify skin microbiota and perform its sensitivity to different soaps used in household.

Figure 3 and Figure 4 show antimicrobial activity of hand washing and toilet gel. Hand washing was the most effective against all the pathogenic strains tested but Citrobacter exhibited high resistant to hand wash There was no observed inhibitory effect on Citrobacter by the soap at all concentrations used. Citrobacter being Gram negative organism has little peptidoglycan in its cell wall and this may hinder the activity of the active components of the soap (fatty acids), which is the cause of its high resistance to soap used in the current study. The resistance of Citrobacter to antimicrobial agents can also be due to chromosomal mutation which lowers the permeability of the bacteria to the agents or acquisition of resistance $(\mathrm{R})$ plasmids and transponsoms. Toilet gel inhibits the growth of Enterobacter, Staphylococcus but least zone was appeared for E.coli. Duru inhibits the growth of S.aureus, Pseudomonas spp., Klebsiella spp., Enterobacter, Citrobacter, E.coli, Proteus, exhibited higher resistance to clear, Tembo and Duru soaps. E.coli was showed resistant to Duru soap, the resistance of E. coli is usually due to chromosomal mutation which lowers the permeability of the bacteria to the soap agents or acquisition of resistance plasmids and tranponsoms. This explained indicate they are less antimicrobial soap.

The present study shows that toilet gel inhibited $S$. aureus at $18 \mathrm{~mm}$, E. coli at $13 \mathrm{~mm}$, Klebsiella spp. at $17 \mathrm{~mm}$. Other study done in Dar es Salaam by Mwambete et al., 2011 Duru and liquid soap was one of tested soaps, Duru soap has showed the inhibition zone of 9.8 , and $15.8 \mathrm{~mm}$ on P.aureginosa, 8.5 and $11.7 \mathrm{~mm}$ on E.coli and $10.2 \mathrm{~mm}$ and $13.5 \mathrm{~mm}$ on S.aureus. Liquid soap were showed $8.4 \mathrm{~mm}$ and $10.7 \mathrm{~mm}$ on P.aureginosa, $9.0 \mathrm{~mm}$ and $10.6 \mathrm{~mm} 0 \mathrm{n}$ E.co$l i$, and $10.5 \mathrm{~mm}$ and $7.4 \mathrm{~mm}$ on $\mathrm{S}$. aureus these number are not far from those obtained in this study to E.coli zone of inhibition $24 \mathrm{~mm}$, Proteus $15 \mathrm{~mm}$, Klebsiella at $13 \mathrm{~mm}$ and s.aureus at $14 \mathrm{~mm}$. difference in inhibition zone may be due to different factors including where the bacteria comes from and the level of antibacterial chemicals containing the soap. This study showed that Gram negative bacteria (E. coli; P. aeruginosa; and K. pneumonia) resist to many soaps used, this result May be explained by the fact that triclosan does not exhibits particular activity against gram negative bacteria due to differences in the cell wall composition.

The study carried out in Thailand at Prince of Songkla University by Ungphaiboon et al. (2005) on antioxidant and antimicrobial activities of turmeric clear liquid soap for wound treatment of HIV patients, the antimicrobial susceptibility test was performed on Escherichia coli, $\mathrm{Ba}$ - cillus subtilis, Pseudomonas aeruginosa, Staphylococcus aureus, Candida albicans and Cryptococcus neoformans. Turmeric extract was inhibited all tested microorganisms except $E$. coli and $P$. aeruginosa, the study was concluding that using turmeric extract in the formulation should improve skin infection treatment and could be considered for scavenging free radicals from inflammatory conditions.

the present study show less effectivity of clear solid soap to E. coli, P.aeruginosa and $S$. aureus but hand washing liquid soap has shown antimicrobial activity to all isolated bacteria Including S. aureus, P.aeruginosa, Klebsiella, proteus, Enterobacter while Citrobacter is resistant to it. Hand washing and toilet gel soaps was demonstrated satisfactory effect, particularly the antibacterial activity, hence buttressing the information written on the soap labels that they possess antibacterial activity. This indicate that they contain some ingredients in their composition which have the ability to inhibit the growth of some bacteria. Hand washing showed the inhibition to S.aureus this may be explained by the fact that triclosan exhibits particular activity against gram positive bacteria due to their cell wall.

The findings of the study conducted on Antimicrobial Activity of Medicated Soaps Commonly Used By Dar es Salaam Residents in Tanzania. 13 medicated soap were used, Duru. protex and liquid soap was one of tested soaps,Duru soap its potential to inhibit bacterial growth with inhibition zone of 9.8 , and $15.8 \mathrm{~mm}$ on P.aureginosa, 8.5 and $11.7 \mathrm{~mm}$ on E.coli and $10.2 \mathrm{~mm}$ and $13.5 \mathrm{~mm}$ on S.aureus. Liquid soap were showed $8.4 \mathrm{~mm}$ and $10.7 \mathrm{~mm}$ on Paureginosa, $9.0 \mathrm{~mm}$ and $10.6 \mathrm{~mm} \mathrm{On} \mathrm{E.coli,} \mathrm{and} 10.5 \mathrm{~mm}$ and $7.4 \mathrm{~mm}$ on S.aureus (Mwambete et al., 2011). In the result of the current study liquid hand washing was effective to S.aureus $(13 \mathrm{~mm})$, on E.coli $(24 \mathrm{~mm})$ and P.aureginosa $(14 \mathrm{~mm})$ this shows the effectiveness of hand washing (zena) to S.aureus, E.coli and P.aureginosa. Clear and Tembo exhibited no inhibition to different microbes tested this may be explained that they possess less antimicrobial component. Clear and Tembo soaps are plain soap. Clear and Tembo soap lacks key ingredient used in killing microorganisms such as triclosan, when the soap is scrubbed into the skin; it helps to release oils and it can't kill bacteria on the surface of the skin.

\section{CONCLUSION}

From skin, clothes and material samples Citrobacter spp., P. aeruginosa, Enterobacter spp., S. aureus, E. coli, Klebsiella $s p p$. and Proteus spp. were isolated. Differences in the level of effectiveness of diff ere nt soaps used against isolated bacteria were observed. The highest antibacterial activity was observed in toilet gel and hand washing soap. These soaps can be used to prevent skin infections and 
transmission of skin pathogens when used in washing. Duru soap has th e prop erty t o inh ibit growth of S.aureus only. However, its antibacterial property is not effective to other bacteria as the commercial plain soap in terms of zone of inhibition. Thus, washing body with Duru soaps is not enough for protection against pathogenic bacteria. In this study, it was proven that clear and tembo are less effective to fight against bacteria.

\section{AKNOWLEDGEMENT}

Gratitude thanks to INES-Ruhengeri microbiology Laboratory for laboratory analysis support. Deep thanks to Susa Village leaders to allows collecting samples in household. May blessing increases your will to support research.

\section{CONFLICT OF INTEREST}

The authors declare that they have no conflict of interest.

\section{AUTHORS' CONTRIBUTION}

Authors contributed equally.

\section{REFERENCES}

- Abbas S, Liaz Hasinain, Adeel A (2009). Antibacterial activity of soaps against daily encountered bacteria. pakistan: university of the punjab.

- Abbas S, Hussain K, All R, Abbas T (2016). Anti-bacterial activity of different soaps available in local market of rawalpindi against daily encountered bacteria. Pharm. Anal. Acta. 7(11): 2153-2435. https://doi.org/10.4172/21532435.1000522

- Adebayo OC, Afolami OI, Oladunmoye MK, Bolaniran T (2018). Comparative Antimicrobial Efficacy of Locally Made African Black Soaps Produced in Akure, Nigeria and Medicated Soaps Against Selected Clinical Skin Pathogens. Acta Scient. Microbiol. 1(3): 33-37. https://doi. org/10.31080/ASMI.2018.01.0026

- Akuoko CP (2019). Bacterial Reduction of Hand Contamination: Hand Rubbing with Alcohol-Based Solution or Hand Washing with Soap and Water. J. Health
Med. Nurs. Vol 67. https://doi.org/10.7176/JHMN/67-09

- Allison EA, Elaine L. Larson, Stuart BL (2007). Consumer Antibacterial Soaps: Effective or Just Risky? Clinical Infectious Diseases. 45: S137-47. https://doi.org/ 10.1086/519255

- Chiller K, Selkin BA, Murakawa GJ (2001). Skin microflora and bacterial infections of the skin. J. Investigati. Dermatol. Symposium Proceed. 6(3): 170-174. https://doi. org/10.1046/j.0022-202x.2001.00043.x

- Gould IM (2009). Antibiotics, skin and soft tissue infection and meticillin -resistant Staphylococcus aureus : cause and effect. Int J Antimicrob Agents. 34 Suppl 1:S8-S11 https:// doi.org/10.1016/S0924-8579(09)70542-4

- Horton RA, Randall LP, Snary EL, Cockrem H, Lotz S, Wearing $H$ (2011). Fecal carriage and shedding density of CTX-M extended-spectrum $\beta$-lactamase-producing Escherichia coli in cattle, chickens, and pigs: implications for environmental contamination and food production. Appl. Environ. Microbiol. 77: 3715-3719. https://doi. org/10.1128/AEM.02831-10

- Ikpoh IS, Lennox JA, Agbo BE, Udoekong NS, Ekpo I.A, Iyam SO (2012). Comparative studies on the effect of locally made black soap and conventional medicated soaps on isolated human skin microflora. J. Microbiol. Biotechnol. Res. 2(4): 533-537.

- Mwambete K, FL (2011). Antimicrobial activity of medicated soaps commonly used by Dar es Salaam resindent in Tanzania. Indian J. Pharmaceut. Sci. 73(1): 92-98. https:// doi.org/10.4103/0250-474X.89765

- Osborne RC, Grube J (1982). Hand disinfection in dental practice. J. Clin. Prev. Dent. 4: 11-15. PMID: 6984830

- Saba R, Adeel A, Shahida H (2009). Antimicrobial activity of soaps against daily encoutered bacteria. African J. Biotechnol. 8(8): 1431-1436.

- Teniola OD, Folounsho, VT, Pelumi SO, Ayomikun E. A, Adebukunola MO (2019). Antimicrobial Activities of Different Soaps on Selected Human Skin Pathogens. J. Adv. Microbiol. 17(2): 1-10. https://doi.org/10.9734/ jamb/2019/v17i230141

- Varsha MC (2016). Studies on antimicrobial activity of antiseptic soaps and herbal soaps against selected human pathogens. J. Scient. Innov. Res. 5(6): 201-204.

- Ungphaiboon S, Supavita T, Singchangchai P, Sungkarak S, Rattanasuwan P, Itharat (2005). A. Study on antioxidant and antimicrobial activities of turmeric clear liquid soap for wound treatment of HIV patients. Songklanakarin J. Sci. Technol. 27(Suppl. 2) : 569-578. 